\title{
UJI EFEKTIVITAS DAUN SAMBUNG NYAWA TERHADAP BAKTERI SALMONELLA TYPHI
}

\section{Melysa ${ }^{1}$ Charles Manurung ${ }^{2}$ Setia Budi Tarigan ${ }^{3}$ Sri Lestari Ramadhani Nasution}

\author{
1,2,3,4 Fakultas Kedokteran Universitas Prima Indonesia \\ 1/oeslimmelysa@gmail.com ${ }^{4}$ srilestari_nasution@yahoo.com
}

\section{Abstrak}

Salmonella typhi adalah bakteri penyebab demam tifoid, yaitu penyakit yang diserbarkan lewat makanan dan minuman yang telah tercemar feses atau kotoran manusia dimana penyakit ini disebabkan oleh suatu kuman yang berbentuk basil yaitu Salmonella typhi. Penelitian ini bertujuan demi mengetahui uji efektifitas ekstrak daun sambung nyawa dengan konsentrasi 25\%, 50\%, 75\%, dan 100\% terhadap bakteri Salmonella typhi dengan kloramfenikol sebagai pembandingnya. Penelitian ini dilakukan di Laboratorium Organik Fakultas Matematika dan Ilmu Pengetahuan Alam Universitas Sumatera utara dan di Laboratorium Farmasi dan Toksikologi Fakultas Farmasi Universitas Sumatera Utara. Penelitian ini dilakukan dengan metode eksperimental desain post-test only design, pengambilan sampel dengan metode Purposive sampling. Uji efektivitas daun sambung nyawa terhadap bakteri salmonella typhi dilakukan dengan cara difusi menggunakan kertas cakram, dengan menghitung diameter zona hambat bakteri terhadap kertas cakram yang sudah dibasahi dengan ekstrak daun sambung nyawa dan kertas cakram yang mengandung kloramfenikol. Hasil penelitian dapat dilihat bahwa pada konsentrasi $25 \%$ - 100\% peningkatan rerata diameter zona hambat terus terjadi, yaitu pada konsentrasi 25\% 11,75 mm, pada konsentrasi 50\% 14,25 mm, pada konsentrasi $75 \%$ 12,65 mm dan pada konsentrasi 100\% 15,05 mm, zona hambat rerata pada kontrol positif berdiameter $26,4 \mathrm{~mm}$ terhadap pertumbuhan bakteri Salmonella typhi. Terdapat hal yang dapat disarankan pada penelitian ini yaitu perlunya dilakukan penelitian pengembangan tentang efektivitas antibakteri ekstrak daun sambung nyawa (Gynura procumbens (Lour.)Merr.) dengan menggunakan konsentrasi yang berbeda untuk menghambat pertumbuhan bakteri Salmonella typh, dan perlunya dilakukan penelitian yang lebih lanjut dengan memakai bagian lainnya dari tumbuhan sambung nyawa (Gynura procumbens (Lour.)Merr.) terhadap bakteri Salmonella typhi.

Kata kunci : Gynura, Demam tifoid, Sambung nyawa, Salmonella typhi, Obat alami

\section{The Effectiveness Test Of Extract Sambung Nyawa Leaves On Salmonella Typhi Bacteria}

\begin{abstract}
Salmonella typhi is a bacterium that causes typhoid fever, which is a disease that is spread through food and drink that has been contaminated with faeces or human feces where the disease is caused by a bacilli-shaped germ that is Salmonella typhi. The aim of this study was to determine the effectiveness of the test for leaf extracts with a concentration of $25 \%, 50 \%, 75 \%$, and $100 \%$ against Salmonella typhi with chloramphenicol as a comparison. at the Organic Laboratory of the Faculty of Mathematics and Natural Sciences, University of North Sumatra and at the Pharmacy and Toxicology Laboratory of the Faculty of Pharmacy, University of North Sumatra. This research was conducted with an experimental method of post-test only design, sampling using purposive sampling method. The effectiveness test of leaf grafting against salmonella typhi bacteria was carried out by diffusion using disc paper, by calculating the diameter of the bacterial inhibition zone on disc paper that had been moistened with extracts of life grafts and disc paper containing chloramphenicol. The results can be seen that at a concentration of 25\% - 100\% an increase in the average diameter of the inhibition zone continues, namely at a concentration of $25 \% 11.75 \mathrm{~mm}$, at a concentration of $50 \% 14.25 \mathrm{~mm}$, at a concentration of $75 \% 12.65 \mathrm{~mm}$ and at a concentration $100 \% 15.05 \mathrm{~mm}$, mean inhibition zone in positive control $26.4 \mathrm{~mm}$ in diameter on the growth of Salmonella typhi bacteria. There are things that can be suggested in this study are the need to develop research on the effectiveness of antibacterial extracts of life-sustaining leaves (Gynura procumbens (Lour.) Merr.) By using different concentrations to inhibit the growth of Salmonella typh bacteria, and the need for further research with use other parts of the graft (Gynura procumbens (Lour.) Merr.) against Salmonella typhi bacteria.Keywords: Gynura, Typhoid fever,Sambung Nyawa, Salmonella typhi, Herbal medicine.
\end{abstract}




\section{PENDAHULUAN}

Dalam pengobatan tradisional, tanaman obat sudah dikenal sejak dahulu tapi penggunaannya belum dimanfaatkan secara maksimal, padahal tidak ada efek samping dari penggunaan obat tradisional seperti yang biasa terjadi pada pengobatan kimiawi. Masyarakat mewariskan tradisi pengetahuan tentang pemanfaatan tumbuhan obat untuk mengatasi masalah kesehatan dari generasi ke generasi, sehingga muncul ciri khas pengobatan tradisional Indonesia yaitu berbagai ramuan herbal. Dengan penggunaan obat yang berasal dari alam, masyarakat mampu mengatasi masalah-masalah kesehatan yang terjadi. (1)

Sambung Nyawa (Gynura procumbens (Lour.)Merr.)adalah tumbuhan yang tumbuh merambat, batangnya berbentuk segiempat beruas, ruas dengan warna hijau dan bercak ungu, tanaman ini berdaun tunggal, daun bertoreh dan berambut halus, bila daunnya diremas akan berbau aromatis. Sambung Nyawa biasanya ditemukan sebagai tumbuhan pengganggu yang tumbuh banyak secara liar di selokan, di perkebunan, padang rumput, dan di pinggiran hutan. ${ }^{(2)(3)}$

Gynura procumbens adalah famili Asteraceae, yang merupakan obat tradisional popular. Di daerah Jawa, Sambung Nyawa dikenal dengan nama 'Ngokilo', sedangkan orang Melayu menyebutnya dengan nama 'Belutas Cina'. Di Malaysia, tanaman ini dikenal dengan nama 'Akar Sabiak', 'Kecam Akar' atau 'Sambung Nyawa'. Diantara komunitas Chinese Malaysia, tanaman ini disebut dengan nama 'Bai Bing Ca'. (4)

Daun Sambung nyawa berpotensi dapat menjadi antimicrobial, karena mengandung senyawa Flavonoid dan juga minyak atsiri. ${ }^{5}$ Bakteri Salmonella typhiadalah kuman penyebab tifus yang merupakan nama lain dari demam tifoid. Paratifus abdominalis dan enteric fevermerupakan nama lain dari demam tifoid. Demam tifoid adalah penyakit yang endemik dan merupakan masalah kesehatan terbanyak pada negara yang sedang berkembang dan beriklim tropis. Di Indonesia demam tifoid merupakan penyebab kematian 3\% dari seluruh kematian, diperkirakan dari 100.000 penduduk lebih kurang ada $300-810$ kasus demam tifoid pertahun. ${ }^{6}$

Insiden demam tifoid di Indonesia banyak ditemukan pada penduduk yang berusia 3-19 tahun. Dalam rumah sakit di Indonesia pada pasien rawat inap,dilaporan oleh Dirjen Bina Kesehatan Masyarakat Departemen kesehatan RI di tahun 2010 bahwa demam tifoid berada pada posisi urutan ketiga dari 10 penyakit terbanyak yaitu berjumlah 41.081 kasus. $^{(7)}$

Berdasarkan menteri kesehatan Indonesia (menkes) peningkatan kasus demam tifoid terus naik setiap tahun dengan rerata jumlah kejadian 500 per 100.000 penduduk dengan persentase kematian sebesar 0.6-5 \%. Angka kejadian ini berkaitan dengan tingkat higienitas individu, kebersihan yang kurang di tempat umum, juga masyarakat yang tidak mendukung perilaku hidup bersih dan sehat ${ }^{(8)}$. Berdasarkan uraian diatas peneliti ingin menguji efektivitas ekstrak daun sambung nyawa (Gynura procumbens (Lour.)Merr.) terhadap bakteri Salmonella typhi.

\section{METODE}

Untuk penelitian ini, bentuk desain penelitian yang dipilih adalah Post-test only design, dengan metode eksperimental dengan menggunakan media nutrient broth (NB) guna mengetahui cara menghambat bakteri Salmonella typhi dengan melihat efektifitas ekstrak daun sambung nyawa (Gynura procumbens (Lour.)Merr.) Pada penelitian ini proses pengambilan data-data dilakukan mulai dari bulan Agustus hingga bulan September tahun 2019 di Laboratorium Organik Fakultas Matematika dan Ilmu Pengetahuan Alam Universitas Sumatera utara dan di Laboratorium Farmasi dan Toksikologi Fakultas Farmasi Universitas Sumatera Utara dengan menggunakan sampel ekstrak daun Sambung Nyawa (Gynura procumbens (Lour.)Merr.) yang akan diuji terhadap bakteri Salmonella typhi.

\section{HASIL}

Dari hasil pengumpulan data yang telah dianalisa, maka didapatkan kesimpulan hasil penelitian dibawah ini. Hasil skrining fitokimia pada Sambung Nyawa (Gynura procumbens (Lour.)Merr.) Tabel 1. Hasil Skrining Fitokimia Sambung Nyawa (Gynura procumbens (Lour.)Merr.)

\begin{tabular}{llll}
\hline No. & Pemeriksaan & Pereaksi & Hasil \\
\hline 1 & Alkaloid & Bouchardart & + \\
& & Maeyer & Wagner \\
& & & + \\
\hline 2 & Steroida dan & Salkowsky & + \\
& Triterpenoid & $\begin{array}{l}\text { Lieberman } \\
\text { Burchad }\end{array}$ & - \\
\hline 3 & Saponin & Aquadest & + \\
& & Aquadest+Alkohol & + \\
& & $96 \%$ & + \\
\hline 4 & Flavonoida & $\mathrm{FeCl}_{3} 5 \%$ & + \\
\hline
\end{tabular}




\begin{tabular}{llll}
\hline & & $\mathrm{H}_{2} \mathrm{SO}_{4(\mathrm{p})}$ & - \\
& & $\mathrm{Mg}_{(\mathrm{s})}+\mathrm{HCl}_{(\mathrm{p})}$ & - \\
\hline 5 & Tanin & $\mathrm{FeCl}_{3} 1 \%$ & + \\
\hline 6 & Glikosida & Mollisch & + \\
\hline
\end{tabular}

Keterangan :

+ (positif) : memiliki kandungan senyawa

- (negatif) : tidak memiliki kandungan senyawa

Menurut hasil uji skrining fitokimia pada Tabel 1. Dapat diketahui bahwa daun Sambung Nyawa (Gynura procumbens (Lour.)Merr.) memiliki kandungan senyawa berupa Alkaloid, Steroida dan Triterpenoid, Saponin, Flavonoida, Tanin, dan Glikosida. Pada penelitian ini metode yang dipakai guna menguji kandungan senyawa metabolit sekunder yang bersifat kualitatif, dalam pengertian mendeteksi apakah terdapat kandungan senyawa metabolit sekunder atau tidak.

Efektivitas antimokroba daun Sambung Nyawa (Gynura procumbens (Lour.)Merr.) pada bakteri Salmonella typhi ditunjukkan dengan adanya zona hambat atau zona bening disekeliling kertas cakram. Jangka sorong digunakan dalam pengukuran diameter zona hambat dengan konsentrasi $25 \%, 50 \%$, $75 \%$, dan $100 \%$ didapat zona hambat seperti tabel dan gambar dibawah ini :

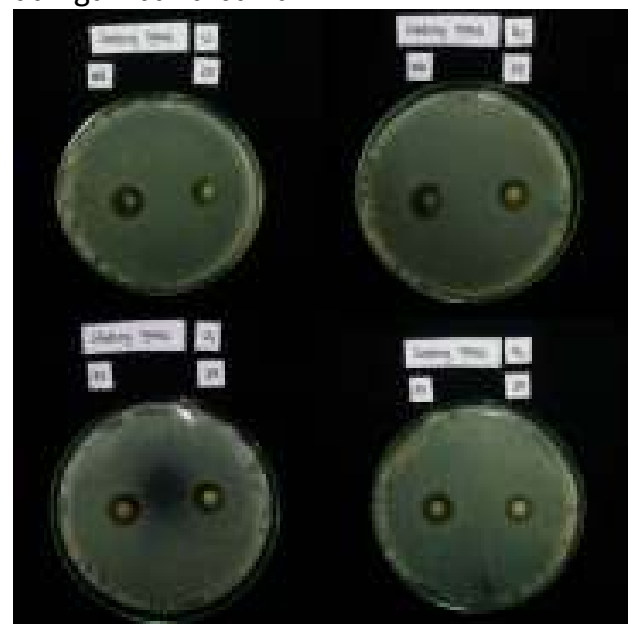

Gambar 1. Pengulangan 1 dan 2 Dengan konsentrasi $25 \%, 50 \%, 75 \%, 100 \%$

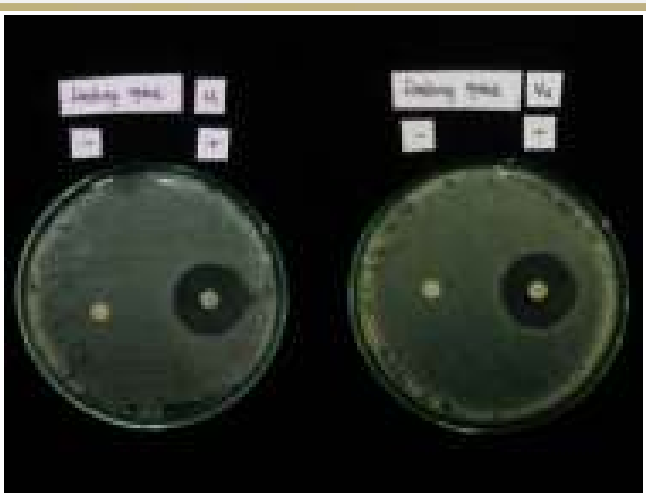

Gambar 2. Pengulangan 1 dan 2 Dengan Kontrol Positif dan Negatif

\begin{tabular}{cccc}
\hline \multirow{2}{*}{$\begin{array}{c}\text { Konsentr } \\
\text { asi }\end{array}$} & \multicolumn{2}{c}{$\begin{array}{c}\text { Diameter Zona Hambat } \\
(\mathrm{mm})\end{array}$} & Rata-rata \\
\cline { 2 - 3 } & $\begin{array}{c}\text { Percobaan } \\
\text { Ke-1 }\end{array}$ & $\begin{array}{c}\text { Percobaan } \\
\text { Ke-2 }\end{array}$ & \\
\hline $25 \%$ & 12,8 & 10,7 & 11,75 \\
\hline $50 \%$ & 13,3 & 15,2 & 14,25 \\
\hline $75 \%$ & 13,2 & 12,1 & 12,65 \\
\hline $100 \%$ & 16,4 & 13,7 & 15,05 \\
\hline $\begin{array}{c}\text { Kontrol } \\
\text { Positif }\end{array}$ & 26,2 & 26,6 & 26,4 \\
\hline $\begin{array}{c}\text { Kontrol } \\
\text { Negatif }\end{array}$ & 0 & 0 & 0 \\
\hline Rata-rata & 13,65 & 13,05 & \\
\hline
\end{tabular}

Tabel 2. Hasil Diameter Zona Hambat Ekstrak Daun Sambung Nyawa Terhadap Pertumbuhan Bakteri Salmonella Typhi

Berdasarkan tabel 2, diketahui pada ekstrak daun sambung nyawa konsentrasi $25 \%$ pada percobaan pertama dan keduasecara berurutan zona hambat yaituberdiameter $12,8 \mathrm{~mm}$ dan diameter 10,7 mm. Pada ekstrak daun sambung nyawa konsentrasi $50 \%$ pada percobaan pertama dan kedua

secara berurutan zona hambat berdiameter $13,3 \mathrm{~mm}$ dan 15,2 $\mathrm{mm}$. Pada ekstrak daun sambung nyawa konsentrasi $75 \%$ memiliki zona hambat berdiameter sebesar 13,2 $\mathrm{mm}$ pada percobaan pertama, dan diameter 12,1 $\mathrm{mm}$ pada percobaan kedua. Zona hambat pada ekstrak daun sambung nyawa konsentrasi $100 \%$ berdiameter $16,4 \mathrm{~mm}$ pada percobaan pertama, dan diameter $13,7 \mathrm{~mm}$ pada percobaan kedua. Nilai rerata pada zona hambat tertinggi adalah di konsentrasi $100 \%$ yaitu diameter $15,05 \mathrm{~mm}$ sedangkan nilai rerata zona hambat terendah adalah di konsentrasi $25 \%$ yaitu diameter $11,75 \mathrm{~mm}$. Pada kontrol positif diperoleh diameter 
zona hambat percobaan pertama adalah $26,2 \mathrm{~mm}$ dan pada percobaan ke-2 diperoleh diameter zona hambat $26,6 \mathrm{~mm}$.

\section{DISKUSI}

Menurut hasil data dari penelitian yang telah dilakukan maka terdapat efektivitas ekstrak daun sambung nyawa, juga terdapat perbedaan antara ekstrak daun sambung nyawa dan kontrol positif kloramfenikol. Hal ini ditunjukan dari pengukuran zona hambat yang tampak di sekitaran kertas cakam dengan memakai alat jangka sorong .

Berdasarkan percobaan yang telah dilaksanakan, bisa disimpulkan bahwa daun sambung nyawa dengan konsentrasi $100 \%$ efektif dalam menghambat bakteri Salmonella typhi dan konsentrasi $25 \%$ adalah yang kurang efektif dalam menghambat bakteri tersebut. Pernyataan ini didapat karena pada konsentrasi $100 \%$ di percobaan pertama diameter zona hambatnya $16,4 \mathrm{~mm}$ dan pada konsentrasi $25 \%$ di percobaan kedua diameter zona hambatnya paling rendah yaitu $10,7 \mathrm{~mm}$. Pada kontrol positif yaitu kloramfenikol menunjukkan bahwa respon hambatan pertumbuhannya tergolong kuat yaitu rerata diameter zona hambat $26,2 \mathrm{~mm}$ pada percobaan pertama maupun kedua. Sedangkan dengan kontrol negatif yaitu aquadest tidak menampakkan terdapatnya zona hambat terhadap bakteri Salmonella typhi. Zona hambat dengan ekstrak daun sambung nyawa terbentuk karena adanya kandungan antimikroba pada daun tersebut seperti flavonoid dan minyak atsiri.

\section{SIMPULAN}

Menurut penelitian yang sudah dilakukan menunjukkan hasil bahwa ekstrak daun sambung nyawa (Gynura procumbens (Lour.)Merr.) pada konsentrasi 25\%, 50\%, 75\%, dan 100\% memiliki efektivitas antibakteri untuk menghambat proses pertumbuhan bakteri Salmonella typhi kemudian didapatkan hasilkonsentrasi yang lebih efektif untuk menghambat bakteri Salmonella typhi yaitu 100\%.

\section{SARAN}

1. Perlunya dilakukan penelitianpengembangan tentang efektivitas antibakteri ekstrak daun sambung nyawa (Gynura procumbens (Lour.)Merr.) dengan menggunakan konsentrasi yang berbeda untuk menghambat pertumbuhan bakteri Salmonella typhi.

2. Perlunya dilakukan penelitian yang lebih lanjut dengan memakai bagian lainnya dari tumbuhan sambung nyawa (Gynura procumbens (Lour.)Merr.) terhadap bakteri Salmonella typhi.

\section{DAFTAR PUSTAKA}

1. Oka IM, Parwata ADI, Kimia J, Kimia L, Fmipa O, Udayana U. Obat Tradisional Oleh I Made Oka Adi Parwata Jurusan Kimia Laboratorium Kimia Organik Fmipa Universitas Udayana 2016. 2016;1-71.

2. Hoesen D. Perbanyakan dan penyimpanan kultur sambung nyawa [gynura procumbens (lour.) Merr.] Dengan teknik in-vitro [In vitro technique propagation and culture maintainance of sambungnyawa \{Gynuraprocumbens (Lour.) Merr.\}]. Ber Biol. 2001;5(4):379-85.

3. Saparinto C, Susiana R. Grow your own medical plant: Panduan Praktis Menanam 51 Tanaman Obat Populer Di Pekarangan ]. 2016.

4. Dalimartha S. Atlas Tumbuhan Obat Indonesia. Trubus Agriwijaya; 1999.

5. Fadli MY. Benefits of Sambung Nyawa (Gynura procumbens ) Subtance as Anticancer. J Major. 2015;4(5):40-3.

6. Cita YP. Bakteri Salmonella typhi dan Demam Tifoid. J Kesehat Masy Sept - Maret 2011. 2011;6(1):42-6.

7. Nurlaila S, Trisnawati E, Selviana. Faktor-faktor yang berhubungan dengan Demam Tifoid pada pasien yang dirawat di RSU.Dr.Soedarso Pontianak Kalimantan Barat. 